Note

\title{
Cloning, Sequencing and Heterologous Expression of the Gene Encoding Glucoamylase from Clostridium thermoamylolyticum and Biochemical Characterization of the Recombinant Enzyme*
}

\author{
(Received August 2, 2003 ; Accepted September 19, 2003)
Naoki Morimoto, ${ }^{* *}$ Tomomi Hayase, ${ }^{* *}$ Naoto Isono, ${ }^{* *}$ Takashi Tochihara, Kenji Watanabe, ${ }^{* * *}$ Hiroyuki Ito and Hirokazu Matsui \\ Department of Applied Bioscience, Graduate School of Agriculture, Hokkaido University \\ (Kita-9, Nishi-9, Kita-ku, Sapporo 060-8589, Japan)
}

\begin{abstract}
Clostridium thermoamylolyticum glucoamylase gene was overexpressed in Escherichia coli cells. This glucoamylase gene consisted of 2133 bp that encoded a 710-amino-acid protein with a molecular mass of $79,920 \mathrm{Da}$. The glucoamylase fell into glycoside hydrolase family 15 , showing $84 \%$ identity and $90 \%$ similarity to an amino acid sequence of Clostridium sp. G0005 glucoamylase, and showing $82 \%$ identity and $87 \%$ similarity to that of Thermoanaerobacterium thermosaccharolyticum glucoamylase. The corresponding sequence to the mature protein was placed under the control of the $\mathrm{T} 7$ promoter as a strong and constitutive promoter. The recombinant glucoamylase was purified by a Ni-NTA column. The molecular mass of the mature glucoamylase was $77 \mathrm{kDa}$ by SDS-PAGE, and it was purified 10-fold with a recovery of $65 \%$. The specific activity was determined to be $1.8 \mathrm{U} / \mathrm{mg}$ for maltose. The value of $K_{\mathrm{m}}$ for maltose was determined to be $5.4 \mathrm{mM}$, and the $k_{0}$ was $7.1 \mathrm{~s}^{-1}$. The optimum $\mathrm{pH}$ of the enzyme was determined to be 4.5 , and more than $80 \%$ of the enzyme activity remained between $\mathrm{pH} 3.5$ and 9.0. The optimum temperature was $65^{\circ} \mathrm{C}$, and more than $80 \%$ of the enzyme activity remained up to $65^{\circ} \mathrm{C}$.
\end{abstract}

Key words: glucoamylase, Clostridium thermoamylolyticum, sequencing, cloning

Glucoamylase (1,4- $\alpha$-D-glucan glucohydrolase, E.C. 3.2.1.3, GA) catalyzes the release of $\beta$-glucose from the non-reducing end of maltodextrin chains. A number of glucoamylases have been isolated from a variety of eukaryotic and prokaryotic organisms, and they are typified by previous reports. ${ }^{1-6)}$ All of them have been compiled in family 15 of classification of the glycoside hydrolase superfamily. ${ }^{7}$ In this paper, we present the cloning using PCR by synthetic oligonucleotides from a nucleotide sequence of Clostridium sp. G0005 glucoamylase, ${ }^{8)}$ sequencing, expression of a glucoamylase gene from Clostridium thermoamylolyticum (ATCC-39251) and biochemical characterization of the recombinant enzyme.

All chemicals were purchased from NACALAI TESQUE. DNA manipulations were performed in E. coli DH5 $\alpha$ (Invitrogen) using standard procedures. Restriction enzymes were from TaKaRa BIOCHEMICALS. Polymerase chain reactions were carried out using LA-Taq polymerase (TaKaRa BIOCHEMICALS) as recommended by the manufacturer. PCR products were sequenced in both orientations with a Li-COR 4000 automated DNA sequencer (Aloka). Chromosomal DNA of C. thermoamylolyticum was prepared as described by Ausubel et al ${ }^{9)}$ In

\footnotetext{
${ }^{*}$ Data deposition: The sequence reported in this paper has been deposited in the DDBJ nucleotide sequence database (accession number AB115912).

${ }^{* *}$ These authors contributed equally to this work.

*** To whom reprint requests may be addressed. (Tel. $+81-11-$ 706-2500, Fax.+81-11-706-3635, E-mail: kenji55@chem.agr. hokudai.ac.jp).
}

the first round amplification, the $C$. thermoamylolyticum glucoamylase gene was amplified by using the above chromosomal DNA as a template with a set of following primers. Two oligonucleotide primers, GA-s (5'-GGG TAG CCG ATT GTA CTG TGG GGC ATT-3' $)$ and GAas $\left(5^{\prime}\right.$-TCG TAT TTA TCG CCG ATG TTG ATG TTT TGC $-3^{\prime}$ ), were designed from the sequence of Clostridium sp. G0005 chromosomal DNA (DDBJ accession number D12818). The PCR amplimers were gel-purified and cloned into pCR2.1-TOPO using TA cloning (Invitrogen), yielding pGA, which contained a complete functional glucoamylase gene. The sequence data for the gene displayed in Fig. 1 has been deposited with DDBJ (accession number AB115912). This glucoamylase gene consisted of $2133 \mathrm{bp}$ that encoded a 710 -amino-acid protein with a molecular mass of 79,920 Da. The glucoamylase showed $84 \%$ identity and $90 \%$ similarity to an amino acid sequence of Clostridium sp. G0005 glucoamylase, ${ }^{8)}$ and showed $82 \%$ identity and $87 \%$ similarity to that of Thermoanaerobacterium thermosaccharolyticum (DSM 572) glucoamylase. ${ }^{10)}$ The glucoamylase had low similarity, showing $22 \%$ amino acid sequence similarity to Thermoactinomyces vulgaris R-47 glucoamylase. ${ }^{11)}$ The putative amino acid sequence of the $C$. thermoamylolyticum glucoamylase was compared with the primary structures of glucoamylases from various eukaryotes, ${ }^{12-15)}$ and the five highly conserved regions, CR1, CR2, CR3, CR4 and CR5 (Fig. 1), that have been reported ${ }^{16)}$ were found in the glucoamylase. The glucoamylase had a primary structure quite different from the structures of eukaryotic gluco- 
GA-s

GGGTAGCCGATTGTACTGTGGGGCATTCGCCCTACTTTTTTTGTCTTTTTATAAAACCGGTTGCACAAATCTTCGATATAATGTAAA GA-NdeI-S $\begin{array}{llllllllllllllllllllllllllllllll}M & \text { L } & \text { L } & \text { E } & \text { A } & \text { M } & \text { K } & \text { L } & \text { N } & \text { R } & \text { K } & \text { L } & \text { I } & \text { K } & \text { Y } & \text { L } & \text { P } & \text { V } & \text { L } & \text { F } & \text { L } & \text { A } & \text { S } & \text { S } & \text { V } & \text { L } & \text { S } & \text { G } & \text { C } & \text { A }\end{array}$ AACAATAATATATCAAACATTAAAATTGAGAGATTGAATAATGTACAAGCAGTAAATGGCCCTGGAGAGGCTGATACTTGGGCTAAAGCT $\begin{array}{llllllllllllllllllllllllllllll}\mathbf{N} & \mathbf{N} & \mathbf{N} & \mathbf{I} & \mathbf{S} & \mathbf{N} & \mathbf{I} & \mathbf{K} & \mathbf{I} & \mathbf{E} & \mathbf{R} & \mathbf{L} & \mathbf{N} & \mathbf{N} & \mathbf{V} & \mathbf{Q} & \mathbf{A} & \mathbf{V} & \mathbf{N} & \mathbf{G} & \mathbf{P} & \mathbf{G} & \mathbf{E} & \mathbf{A} & \mathbf{D} & \mathbf{T} & \mathbf{W} & \mathbf{A} & \mathbf{K} & \mathbf{A}\end{array}$ CAGAAACAAGGTGTAGGGACTGCAAACAACTATACTTCCAAAGTATGGTTTACCATTGCAGACGGAGGGATATCTGAGGTTTACTATCCG $\begin{array}{lllllllllllllllllllllllllllllllll}Q & K & Q & G & V & G & T & A & N & N & Y & T & S & K & V & \text { W } & F & T & I & A & D & G & G & I & S & E & V & Y & Y & P & & & \end{array}$

271 ACTATAGATACTGCTGATGTAAAGGATATTAAATTCTTTGTGACAGATGGAAAAACGTTTGTCTCAGATGAGACAAAAGACACAATAACC

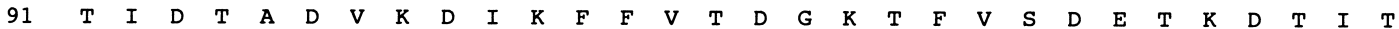

361 AAAGTCGAAAAGTTTACTGAAAAATCGTTGGGGTATAAAATCATTAACACAGATAAAGAAGGGAGATATAAGATAACTAAAGAAATATTT $\begin{array}{lllllllllllllllllllllllllllllllll}121 & \text { K } & \text { V } & \text { E } & \text { K } & \text { F } & \text { T } & \text { E } & \text { K } & \text { S } & \text { L } & \text { G } & \text { Y } & \text { K } & \text { I } & \text { I } & \text { N } & \text { T } & \text { D } & \text { K } & \text { E } & \text { G } & \text { R } & \text { Y } & \text { K } & \text { I } & \text { T } & \text { K } & \text { E } & \text { I } & \text { F }\end{array}$

451 ACGGATGTAAAGAGGAATTCTCTCGTAATTAAAACGAAGTTTGAAGCCTTAAAAGGCAATGTTGATGATTACAGGCTTTACGTAATGTGT $\begin{array}{llllllllllllllllllllllllllllllll}151 & \text { T } & \text { D } & \text { V } & \text { K } & R & \text { N } & \text { S } & \text { L } & \text { V } & \text { I } & \text { K } & \text { T } & \text { K } & \text { F } & \text { E } & \text { A } & \text { L } & \text { K } & \text { G } & \text { N } & \text { V } & \text { D } & \text { D } & \text { Y } & R & \text { L } & \text { Y } & \text { V } & M & \text { C }\end{array}$

541 GATCCTCATGTAAAAAATCAGGGCAAATATAATGAAGGATATGCAGTTAAGGCAAATGGCAATGTTGCGCTAATTGCTGAAAGAGATGGA

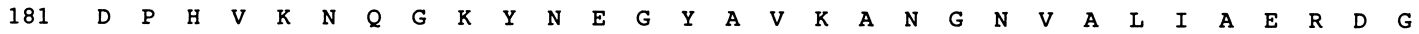

631 ATTTACACTGCATTGTCATCTGACATAGGATGGAAAAAGTATTCGATAGGGTATTATAAAGTAAATGACATTGAGACCGATCTTTATAAA

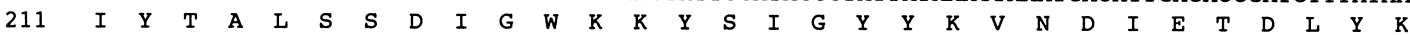

721 AATATGCAAATGACTTACAATTACGACAGTGCAAGAGGCAACATCATAGAAGGTGCTGAGATAGATCTTAAGAAAAACAGGCAATTTGAA

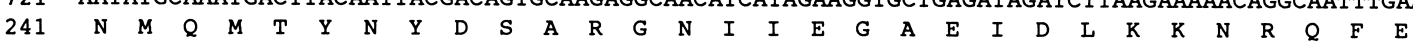

811 ATCGTTCTGTCTTTCGGACAGAGTGAAGACGAGGCAGTAAAAACAAACATGGAAACTTTAAATGATAATTATGACAGCTTAAAGAAAGCG $\begin{array}{lllllllllllllllllllllllllllllll}271 & I & V & L & S & F & G & Q & S & E & D & E & A & V & K & T & N & M & E & T & L & N & D & N & Y & D & S & L & K & K & A\end{array}$

901 TATATAGACCAATGGGAGAAGTATTGCGATAGCCTTAATGACTTTGGAGGAAAAGCAAATTCACTGTATTTTAACAGTATGATGATATTA \begin{tabular}{llllllllllllllllllllllllllllllll}
301 & $Y$ & $I$ & $D$ & $Q$ & $W$ & $E$ & $K$ & $Y$ & $C$ & $D$ & $S$ & $L$ & $N$ & $D$ & $F$ & $G$ & $G$ & $K$ & $A$ & $N$ & $S$ & $L$ & $Y$ & $F$ & $N$ & $S$ & $M$ & $M$ & $I$ & $L$ \\
\hline
\end{tabular}

AGGCCAGTGAAGACAAGACAAACAAAGGTGCTTATATAGCATCGCTATCTATTCCGTGGGGTGATGGCCAAGAAGATGACAATATTGGT \begin{tabular}{llllllllllllllllllllllllllllll}
$K$ & $A$ & $S$ & $E$ & $D$ & $K$ & $T$ & $N$ & $K$ & $G$ & $A$ & $Y$ & $I$ & $A$ & $S$ & L & $S$ & $I$ & $P$ & W & G & D & $G$ & $Q$ & $E$ & $D$ & $D$ & $N$ & $I$ & $G$ \\
\hline
\end{tabular}

GGCTACCATCTCGTATGGTCAAGAGATCTGTACCATGTAGCGAATGCATTTATTGTTGCTGGTGATACTGATTCGGCAAATAGAGCACTG $\begin{array}{llllllllllllllllllllllllllllllll}G & \text { Y } & \text { H } & \text { L } & \text { V } & \text { W } & \text { S } & \text { R } & \text { D } & \text { L } & \text { Y } & \text { H } & \text { V } & \text { A } & \text { N } & \text { A } & \text { F } & \text { I } & \text { V } & \text { A } & \text { G } & \text { D } & \text { T } & \text { D } & \text { S } & \text { A } & \text { N } & R & A & \text { L }\end{array}$

GATTATTTAGACAAAGTAGTGAAAGACAATGGAATGATTCCTCAAAATACATGGATAAATGGAAGGCCTTATTGGACAGGCATACAGCTT \begin{tabular}{lllllllllllllllllllllllllllllll}
$D$ & $Y$ & $L$ & $D$ & $K$ & $V$ & $V$ & $K$ & $D$ & $N$ & $G$ & $M$ & $I$ & $P$ & $Q$ & $N$ & $T$ & $W$ & $I$ & $N$ & $G$ & $R$ & $P$ & $Y$ & $W$ & $T$ & $G$ & $I$ & $Q$ & $L$ \\
\hline
\end{tabular} GATGAGCAGGCGGATCCAATAATATTAAGCTATAGGTTGAAAAGATACGATCTCTATGAAAGTCTTGTTAAGCCTTTGGCGGATTTCATC \begin{tabular}{llllllllllllllllllllllllllllllll}
$D$ & $E$ & $Q$ & $A$ & $D$ & $P$ & $I$ & $I$ & $L$ & $S$ & $Y$ & $R$ & $L$ & $K$ & $R$ & $Y$ & $D$ & $L$ & $Y$ & $E$ & $S$ & $L$ & $V$ & $K$ & $P$ & $L$ & $A$ & $D$ & $F$ & $I$ \\
\hline
\end{tabular} ATGAAAATAGGCCCTAAGACGGGACAAGAAAGATGGGAAGAAATAGGTGGATATTCGCCAGCAACATTGGCTTCAGAAGTAGCTGGACTT \begin{tabular}{llllllllllllllllllllllllllllllll}
$M$ & $K$ & $I$ & $G$ & $P$ & $K$ & $T$ & $G$ & $Q$ & $E$ & $R$ & W & E & E & I & G & G & Y & S & P & A & T & L & A & S & E & V & A & G & L \\
\hline
\end{tabular}

ACATGTGCTGCGTATATAGCTGAACAAAATAAGGACTTTGAATCTGCTAAAAAATATCAAGAAAAGGCGGATAATTGGCAAAGGCTTAT

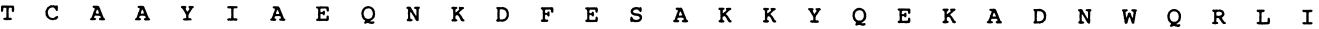

1531 GACAACCTAACTTACACAGAAAAAGGCCCATTGGGAGATGGTCACTATTATATAAGGATAGCAGGGCTTCCAGATCCAAATGCCGATTTC $\begin{array}{lllllllllllllllllllllllllllllll}511 & D & N & L & T & Y & T & E & K & G & P & L & G & D & G & H & Y & Y & I & R & I & A & G & L & P & D & P & N & A & D & F\end{array}$

1621 ATGATAAGCATAGCGAATGGCGGTGGTGTATACGACCAAAAAGAAATCGTGGATCCAAGTTTTCTGGAACTTGTAAGGCTTGGAGTAAAA $\begin{array}{lllllllllllllllllllllllllllllllll}541 & M & I & S & I & A & N & G & G & G & V & Y & D & Q & K & E & I & V & D & P & S & F & L & E & L & V & R & L & G & V & K\end{array}$

1711 TCAGCAGATGACCCTAAAATACTAAATACGCTGAAAGTCGTGGATGAAACAATAAAAGTCGATACACCGAAAGGACCATCATGGTATAGG $\begin{array}{lllllllllllllllllllllllllllllll}571 & S & A & D & D & P & K & I & L & N & T & L & K & V & V & D & E & T & I & K & V & D & T & P & K & G & P & S & W & Y & R\end{array}$

1801 TATAATCATGATGGATATGGTGAGATGTCTAAGACAGAACTATATCATGGGACAGGAAAAGGAAGATTGTGGCCACTGCTTACAGGTGAG $\begin{array}{llllllllllllllllllllllllllllllll}601 & Y & N & H & D & G & Y & G & E & M & S & K & T & E & L & Y & H & G & T & G & K & G & R & L & W & P & L & L & T & G & E\end{array}$

1891 AGAGGCATGTACGAAATTGCTGCAGGAAAAGATGCAACATCTTATGTGAAAGCAATGGAGAACTTTGCAAACGAAAGCGGTATAATATCT

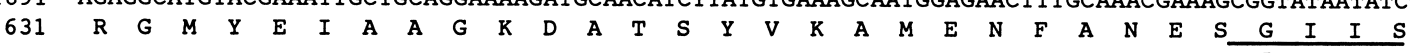

1981 GAGCAAGTATGGGAAGATACTGGACTTCCTACTGATTCAGCATCACCGCTTAATTGGGCACATGCTGAATATGTGATATTATTTGCATCA

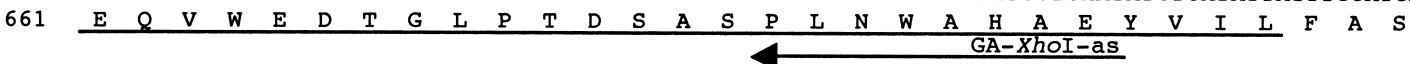

2071 AATATAGAACACAAGGTACTTGATATGCCAGACATCGTTTATAAAAGGTATGCTTCAAAGTGATACACAGATTTTCCGGATGTAATATCC $\begin{array}{lllllllllllllllllllllll}691 & N & I & E & H & K & V & L & D & M & P & D & I & V & Y & K & R & Y & A & S & K & \text { * }\end{array}$

2161 GGGGAATCTGTTTTTCGTTGTTTAAATGAAGTATAATTGTGTATGAGAATATGAATTTGGAGTGATAATTATTGCAAAACATCAACATCG 2251 $\frac{\text { GCGATAAATACGA }}{\text { GA-as }}$

Fig. 1. Nucleotide and deduced amino acid sequences of the glucoamylase from C. thermoamylolyticum.

The deduced gene products are indicated in the one-letter code under the nucleotide sequence. Box shows the signal peptide region. The five highly conserved regions, CR1, CR2, CR3, CR4 and CR5, are underlined. The location of the two sets of primers, GA-s/GA-as and GA-NdeI-s/GA-XhoI-as, are indicated with arrows. 
amylases, but its optimum $\mathrm{pH}$ and temperature were similar. The N-terminal sequence was identical to the sequence starting 29 residues, the 28-residue sequence upstream of N-terminal sequence showed the characteristics of prokaryotic signal peptide. The site of cleavage of a signal from the glucoamylase was predicted by PSORT program. The predicted site resembled a cleavage site of Clostridium sp. G0005 glucoamylase. ${ }^{8)}$ Ohnishi et al ${ }^{8)}$ supposed that the $5^{\prime}$-flanking region or the putative region coding the signal sequence for lipoprotein secretion of a glucoamylase was harmful to $E$. coli cells. We constructed an inducible expression plasmid from pGA for the glucoamylase used in this study with $\mathrm{N}$ terminus deleted using PCR by synthetic oligonucleotides. The glucoamylase gene was cloned into the pET-23a $(+)$ (Novagen) expression vector with a $\mathrm{His}_{6}$-tag at the $\mathrm{C}$ terminus. This expression plasmid was constructed from the pGA to express the glucoamylase. This gene was amplified by PCR using the following primers: GA-NdeI-s ( $5^{\prime}$ G CTA CAT ATG TGC GCT AAC AAT AAT-3' ${ }^{\prime}$ ) and GA-XhoI-as (5'-C TGT CTC GAG CTT TGA AGC ATA CCT-3') (Fig. 1). The restriction sites CAT ATG for NdeI and CTC GAG for XhoI designed in the primers are bold. The resultant products were sequenced to confirm PCR fidelity and cloned as NdeI-XhoI fragment into the same site of pET-23a $(+)$, yielding an expression construct, pETGA. E. coli BL21(DE3)pLysS was used as a host for the expression of the glucoamylase gene. One of the transformants was used for $10 \mathrm{~mL}$ seed culture with ampicillin $(100 \mu \mathrm{g} / \mathrm{mL})$ and chloramphenicol (34 $\mu \mathrm{g}$ / $\mathrm{mL})$ at $37^{\circ} \mathrm{C}$ and $250 \mathrm{rpm}$. The seed culture was used to inoculate 1 liter LB medium at the same antibiotic concentrations as above. This culture was propagated at 200 $\mathrm{rpm}$ and $30^{\circ} \mathrm{C}$ to a mid-log phase of growth $\left(\mathrm{OD}_{600}=0.6\right.$ to 0.8 ), cooled to $4^{\circ} \mathrm{C}$ for $10 \mathrm{~min}$ and induced with 100 $\mu \mathrm{M}$ isopropyl $\beta$-D-thiogalactoside. The culture was continued for an additional $9 \mathrm{~h}$ at $30^{\circ} \mathrm{C}$. Expressed proteins were checked with $10.0 \%$-resolving/4.8\%-stacking gel of post Ni-NTA column (5 mL, Novagen) fractions by Coomassie Brilliant Blue stain.

Glucoamylase activity was determined as the amount of glucose liberated from $0.2 \%$ maltose at $30^{\circ} \mathrm{C}$ in $100 \mathrm{~mm}$ sodium acetate buffer ( $\mathrm{pH} 5.0$ ), using a Glucose AR-II Test (Wako Pure Chemical), as described previously. ${ }^{17)}$ The purity of the protein was verified by SDS-PAGE. The molecular mass of the expressed protein was $77 \mathrm{kDa}$ by SDS-PAGE (Fig. 2), which was similar to the calculated molecular mass from the gene. The recombinant enzyme was purified 10 -fold with a recovery of $65 \%$. In the purification procedure described above, $100 \mathrm{mg} / \mathrm{L}$ of the glucoamylase protein was isolated. The specific activity was determined to be $1.8 \mathrm{U} / \mathrm{mg}$ for maltose. The $\mathrm{N}$-terminal sequence was determined according to Edman degradation, using an Applied Biosystems procise ${ }^{\mathrm{TM}}$ 491-HS. The first 7 amino acids (CANNNIS) of the recombinant glucoamylase were sequenced. The result revealed that the recombinant glucoamylase from $E$. coli was correctly cut off at the initial methionine residue.

The value of $K_{\mathrm{m}}$ for maltose was determined to be 5.4 $\mathrm{mM}$, and the $k_{0}$ was $7.1 \mathrm{~s}^{-1}$ (Fig. 3A). The optimum $\mathrm{pH}$ of the enzyme was determined to be 4.5 (Fig. 3B), and more

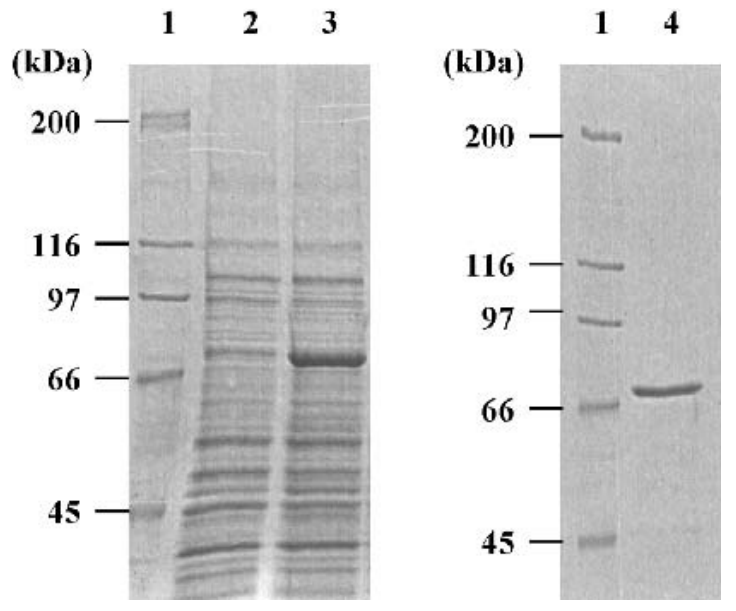

Fig. 2. SDS-PAGE of the recombinant glucoamylase.

Lane 1, protein marker; 2, extract from E. coli harboring pET-23a $(+)$ (negative control); 3, extract from E. coli harboring pETGA; 4, purified recombinant glucoamylase.
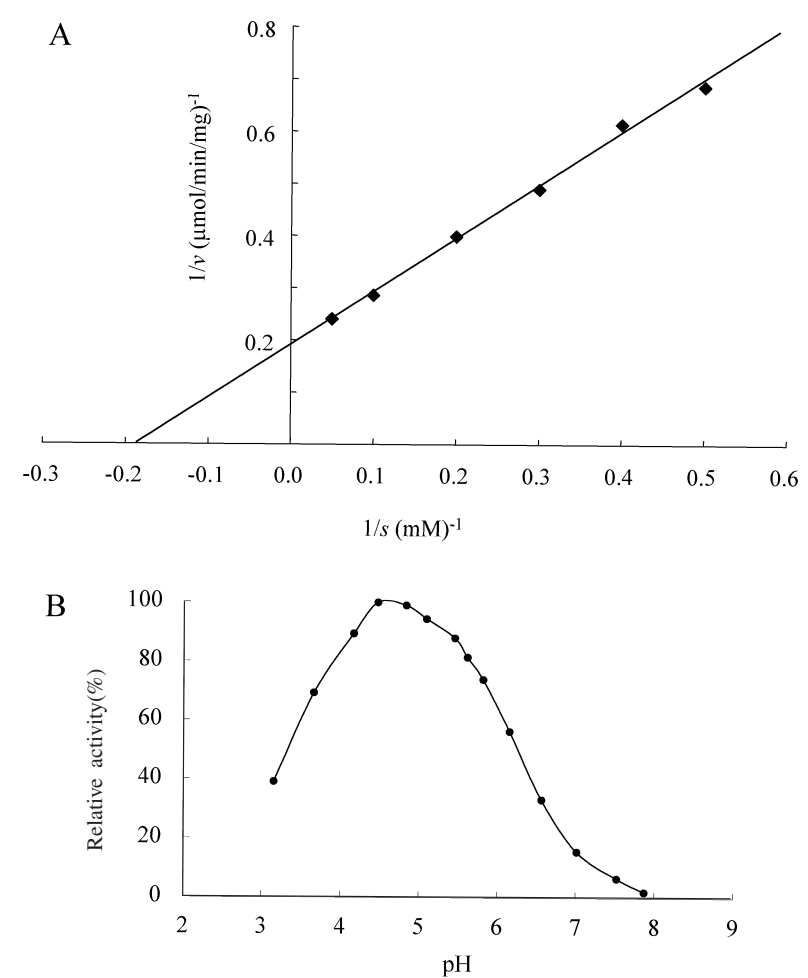

Fig. 3. Properties of the recombinant glucoamylase.

(A) Lineweaver-Burk plot for hydrolysis of maltose by the purified glucoamylase. The maltose concentrations were 2.0, 2.5, 3.3, 5.0, 10.0 and $20.0 \mathrm{mM}$. (B) Effect of the $\mathrm{pH}$ on the activity of the purified glucoamylase. The initial rates were determined at the $\mathrm{pH}$ values in the range of 3.2-7.9 using $100 \mathrm{mM}$ of the buffer citric acid- $\mathrm{Na}_{2} \mathrm{HPO}_{4}$.

than $80 \%$ of the enzyme activity remained between $\mathrm{pH}$ 3.5 and 9.0 at $4{ }^{\circ} \mathrm{C}$ for $20 \mathrm{~h}$. The optimum temperature was $65^{\circ} \mathrm{C}$, and more than $80 \%$ of the enzyme activity remained up to $65^{\circ} \mathrm{C}$ when the enzyme was incubated at various temperatures for $15 \mathrm{~min}$. All the characteristics of the recombinant glucoamylase were similar to those of a glucoamylase from Clostridium sp. G0005. ${ }^{5}$

This work was supported by grants-in-aid for science research from the Ministry of Education, Science, Sports and Culture, Japan (Grants 11660068 and 13660071 to H. I. and 11460032 to H. M.). 


\section{REFERENCES}

1 ) Y. Yamasaki, Y. Suzuki and J. Ozawa: Three forms of alphaglucosidase from Aspergillus awamori. Agric. Biol. Chem., 41, 2149-2161 (1977).

2 ) T. Takahashi, Y. Tsuchida and M. Irie: Purification and some properties of three forms of glucoamylase from a Rhizopus species. J. Biochem., 84, 1183-1194 (1978).

3 ) E. Boel, I. Hjort, B. Svensson, F. Norris, K.E. Norris and N.P. Fill: Glucoamylases G1 and G2 from Aspergillus niger are synthesized from two different but closely related mRNAs. EMBO J., 3, 1097-1102 (1984).

4 ) T. Tanaka, T. Ashikari, N. Nakamura, N. Kiuchi, Y. Shibano, T. Amachi and H. Yoshizumi: Comparison of amino acid sequences of three glucoamylases and their structure-function relationships. Agric. Biol. Chem., 50, 965-969 (1986).

5 ) H. Ohnishi, H. Sakai and T. Ohta: Purification and some properties of a glucoamylase from Clostridium sp. G0005. Agric. Biol. Chem., 55, 1901-1902 (1991).

6 ) U. Specka, F. Mayer and G. Antranikian: Purification and properties of a thermoactive glucoamylase from Clostridium thermosaccharolyticum. Appl. Environ. Microbiol., 57, 23172323 (1991).

7 ) B. Henrissat: A classification of glycosyl hydrolases based on amino acid sequence similarities. Biochem. J., 280, 309-316 (1991).

8 ) H. Ohnishi, H. Kitamura, T. Minowa, H. Sakai and T. Ohta: Molecular cloning of a glucoamylase gene from a thermophilic Clostridium and kinetics of the cloned enzyme. Eur. J. Biochem., 207, 413-418 (1992).

9 ) F.M. Ausubel, R. Brent, R. Eingston, D.D. Moore, J.G. Seidman, J.A. Smith and K. Struhl: Current Protocols in Molecular Biology, Wiley, New York, 2.4.1-2.4.5 (1987).

10) A. Ducki, O. Grundmann, L. Konermann, F. Mayer and M. Hoppert: Glucoamylase from Thermoanaerobacterium thermosaccharolyticum: Sequence studies and analysis of the macromolecular architecture of the enzyme. J. Gen. Appl. Microbiol., 44, 327-335 (1998).

11) R. Uotsu-Tomita, T. Tonozuka, H. Sakai and Y. Sakano: Novel glucoamylase-type enzymes from Thermoactinomyces vulgaris and Methanococcus jannaschii whose genes are found in the flanking region of the alpha-amylase genes. Appl. Microbiol. Biotechnol., 56, 465-473 (2001).

12) J.H. Nunberg, J.H. Meade, G. Cole, F.C. Lawyer, P. McCabe, V. Schweickart, R. Tal, V.P. Wittman, J.E. Flatgaard and M.A. Innis: Molecular cloning and characterization of the glucoamylase gene of Aspergillus awamori. Mol. Cell. Biol., 4, 23062315 (1984)

13) I. Yamashita, K. Suzuki and S. Fukui: Nucleotide sequence of the extracellular glucoamylase gene STA1 in the yeast Sac- charomyces diastaticus. J. Bacteriol., 161, 567-573 (1985).

14) T. Ashikari, N. Nakamura, Y. Tanaka, N. Kiuchi, Y. Shibano, T. Tanaka, T. Amachi and H. Yoshizumi: Rhizopus rawstarch-degrading glucoamylase: Its cloning and expression in yeast. Agric. Biol. Chem., 50, 957-964 (1986).

15) A.E.I. Vainio, H.T. Torkkeli, T. Tuusa, S.A. Aho, B.R. Fagerstrom and M.P. Korhola: Cloning and expression of Hormoconis resinae glucoamylase $\mathrm{P}$ cDNA in Saccharomyces cerevisiae. Curr. Genet., 24, 38-44 (1993).

16) P.M. Coutinho and P.J. Reilly: Structure-function relationships in the catalytic and starch binding domains of glucoamylase. Protein Eng., 7, 393-400 (1994).

17) S. Chiba, S. Inomata, H. Matsui and T. Shimomura: Purification and properties of an $\alpha$-glucosidase (glucoamylase) in sugar beet seed. Agric. Biol. Chem., 42, 241-245 (1978).

\section{Clostridium thermoamylolyticum 由来 glucoamylase 遺伝子の単離, 発現および組換え酵素の諸性質}

森本奈保喜，早瀬友美，磯野直人，栃原孝志 渡辺賢二，伊藤浩之，松井博和 北海道大学大学院農学研究科

(060-8589 札幌市北区北 9 条西 9 丁目)

Clostridium thermoamylolyticum 株染色体 DNA 鋳型と し PCRによって 2133 bp の open reading frameをもち,710 アミノ酸残基を翻訳産物とする glucoamylase 遺伝子 (Fig. 1) を取得した. 得られた推定 glucoamylaseアミノ 酸配列は Clostridium sp. G0005 由来 glucoamylase に対して $84 \%$ 一致し, $90 \%$ の相同性を示し, Thermoanaerobacterium thermosaccharolyticum 由来 glucoamylase に対しては $82 \%$

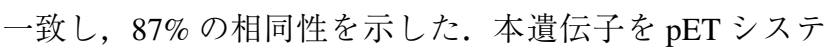
ムを用い大腸菌により発現した。形質転換大腸菌の粗抽 出液より Ni-NTA カラムクロマトグラフィーを用い, 精 製倍率 10 倍, 回収率 $65 \%$, 比活性 $1.8 \mathrm{U} / \mathrm{mg}$ の精製 glucoamylaseを得た。得られた精製酵素は，分子量 $77 \mathrm{kDa}$, maltose に対する $K \mathrm{~m}$ は $5.4 \mathrm{mM}, k_{0}$ は $7.1 \mathrm{~s}^{-1}$, 至適 $\mathrm{pH}$ は 4.5 , 至適温度は $65^{\circ} \mathrm{C}$ であった。本酵素は maltose を基質 として用いた場合，上記原核微生物由来 glucoamylase と 同様の性質を示した. 